\title{
Why Do Political Action Committees Give Money to Candidates? \\ Campaign Contributions, Policy Choices, and Election Outcomes
}

\author{
Christopher Magee*
}

* Department of Economics, Bard College, Annandale-on-Hudson, NY 12504, magee@ bard.edu. Thanks for helpful comments are due members of the Jerome Levy Institute who attended the presentation of this paper as well as Nic Tideman. 


\section{INTRODUCTION}

Rational political action committees (PACs) will give campaign contributions to candidates for two main reasons. Either the contributions are intended to influence the actions taken by winning candidates once they are in office, or they are intended to affect the outcome of the election. Grossman and Helpman (1996) refer to the former reason as an influence motive and the latter as an electoral motive for campaign contributions. Stated more blandly, a PAC can manipulate government policies either by buying policies directly from legislators or by buying elections. In the latter case, the PAC attempts to sway the election in favor of the candidate whose views are most in line with that of the PAC.

This paper attempts to answer the question: do political action committees give money to candidates to influence the positions they adopt or to influence the outcome of the election? Five major policy issues in the 1996 congressional elections are examined: the North American Free Trade Agreement, the Family and Medical Leave Act, a ban on partial birth abortions, cuts in the B-2 bomber program, and gun control. The results suggest that interested political action committees give campaign contributions to challengers primarily in order to affect the outcome of the election. Campaign contributions to challengers significantly affect the election outcome, but they do not affect the policy positions adopted by challengers on any of the five issues. The results about contributions to incumbents are less clear-cut. Contributions received by incumbents do not raise their chances of winning the election, and on only one of the six issues examined do they significantly raise the probability the incumbent will adopt a policy stance favorable to the interest group. Contributions do, however, flow more readily to incumbents who are able, by virtue of a leadership position in Congress or because they are members of relevant committees, to provide important services to interest groups.

The paper adds to the existing literature in a number of ways. First, it is the only empirical paper to estimate the effect of campaign contributions on both incumbent and challenger policy positions before they are elected to office. Many studies examine the impact of campaign contributions on legislators in office, but there is clearly a sample selection issue involved in each of these studies since many viable candidates are excluded from the sample by virtue of having lost the election. Because it includes both candidates, this study can also answer related questions of interest. Do interest groups consider the policy positions adopted by 
both candidates in the election in determining the campaign donations they will give to each one? What effect do candidates' personal characteristics, as opposed to the characteristics of the congressional district, have on the policy positions they adopt?

The next section provides a brief literature review on the role of campaign contributions in determining election outcomes and in affecting legislators' policy choices. Section 3 develops a simple theoretical model of PAC contribution behavior, and section 4 adapts the model for use in the empirical estimation. Sections 5 and 6 present the empirical results and concluding remarks.

\section{LITERATURE REVIEW}

There have been many papers in the economics and political science literatures that have examined whether campaign contributions affect election outcomes and other papers have examined the effect of campaign contributions on legislator policy positions. Very few have looked at both reasons for PACs to give money, however, and have tried to parse out empirically the campaign contributions that are given to affect policy choices from those that affect election outcomes, as this papers attempts to do.

Two studies that do attempt to judge whether campaign contributions are given because of an electoral motive or an influence motive are by Stephen Bronars and John Lott (1997) and by Thomas Stratmann (1998). Bronars and Lott (1997) test whether campaign contributions affect how congress members vote by examining their voting patterns in their last congressional cycle before retirement. If PAC contributions are pulling politicians away from voting in their preferred manner, they should move back to their preferred policy position after announcing their upcoming retirement because reelection is no longer a goal. Despite a large decline in campaign contributions received during their last election cycle, retiring legislators do not change their voting patterns in any significant manner. Bronars and Lott interpret this evidence to mean that PAC money does not influence how legislators vote, but rather that PACs are successful at sorting into office candidates who support their positions. Further evidence that campaign contributions are given with an electoral motive comes from interviews of 20 major political action committees. These groups stated that they never gave to both candidates in an election simultaneously except in exceptional circumstances. Poole and Romer (1985) also 
noted that few interest groups give to both candidates in an election, as they might if the contributors were trying to affect candidates' policy choices.

Stratmann (1998) investigates whether campaign donations are intended for electoral or for influence purposes by looking at the timing of campaign contributions. He finds that farm PACs increased the number and amount of weekly contributions around the time of farm subsidy votes in Congress. The amount of the increase due to the farm subsidy vote was greater than the increase in contributions at the time of primary elections but smaller than the increase at the time of the general election. Thus, he concludes that PACs give campaign money to affect both elections and legislator behavior.

Empirical evidence from other studies is also mixed on whether campaign contributions affect legislative voting behavior. Answering the question is complicated by the fact that campaign contributions are endogenous - interest groups with an electoral motive give donations to candidates who would likely support the group's position even in the absence of the contribution. Chappell (1982) finds that when he controls for their endogeneity, campaign contributions do not significantly affect legislative voting in any of the seven issues he examines. Stratmann (1991), however, uses the same empirical method to show that contributions significantly affect legislators' votes on eight out of ten agricultural policy bills analyzed. Baldwin and Magee (1999) find that contributions from business and labor groups play an important role in determining representatives' voting on the North American Free Trade Agreement, on the GATT Uruguay Round Agreement, and on granting fast-track negotiating authority to President Clinton in 1998. In a review of the literature, Bender and Lott (1996) conclude that politicians vote in their constituent interests in "the vast majority of cases." They argue that when campaign contributions do affect legislators' voting behavior, the deviation between the representatives' actions and constituency interests is not large. Morton and Cameron (1992) suggest that campaign money is more likely to affect legislators' behavior when the economic effects of the bills under consideration are concentrated on particular interest groups and when the issues are less publicly visible.

The effect of campaign contributions on election outcomes is also somewhat in dispute. The "early empirical evidence" according to Morton and Cameron (1992) and the "conventional wisdom" according to Levitt (1995) is that election spending by candidates has a very large impact on election outcomes, but that spending by incumbents is relatively unproductive. This view is argued strongly by Jacobson $(1978,1985)$, who finds little or no effect of incumbent 
spending on election results but very large effects of challenger expenditures. Abramowitz (1988) supports this result as well. He finds that campaign spending by challengers has a much larger effect on senate election outcomes than incumbent expenditures. Challenger spending, in fact, is "the single most important variable affecting an incumbent senator's chance of being reelected.” (p. 397)

Green and Krasno (1988) and Levitt (1994) disagree with the view that challenger spending has a much bigger effect on election outcomes than incumbent spending, but for different reasons. Green and Krasno find that when a new measure of challenger political quality is included in the regressions, the incumbent's spending has a much bigger effect on the election outcome than previous estimates had suggested. Levitt (1994) uses repeated elections between the same two candidates to control for the political quality of each. He finds that spending by challengers and spending by incumbents have a similar, very small impact on the election results. Thus, the empirical literature is divided about the effects of campaign money on both legislator voting behavior and election outcomes.

\section{A MODEL OF PAC BEHAVIOR}

Committees are assumed to behave rationally, an assumption that Stratmann (1992) supports with empirical evidence. Suppose that a lobby cares about the outcome of bill $\mathrm{j}$ that will be brought up in the next Congress. Let $\Pi$ be the utility or the profits of the lobby members, and $P_{j}$ be the policy outcome of the bill. For simplicity, assume that there are only two outcomes: either the bill passes Congress $\left(\mathrm{P}_{\mathrm{j}}=1\right)$, or it fails to pass $\left(\mathrm{P}_{\mathrm{j}}=0\right)$. The lobby's expected profits are

$$
E(\Pi)=\operatorname{Pr}\left(P_{j}=1\right) \Pi_{1}+\left(1-\operatorname{Pr}\left(P_{j}=1\right)\right) \Pi_{0}+S-C,
$$

where $\Pi_{1}$ represents the lobby's utility when the bill passes, $\Pi_{0}$ is the utility when the bill fails, $\mathrm{C}$ is the lobby's campaign contribution, and $\mathrm{S}$ represents the dollar value of unobserved services provided to the lobby by legislators. These unobserved agenda development services include representatives writing or amending bills and using their influence in committees to promote or hinder legislation.

Suppose that there are two candidates for office in each election to the legislature, which has $\mathrm{N}$ total seats. The probability that the bill passes the legislature is 


$$
\operatorname{Pr}\left(P_{j}=1\right)=\operatorname{Pr}\left({ }_{k=1}^{N}\left(\gamma_{k m} p_{j k m}+\left(1-\gamma_{k m}\right) p_{j k(-m)}\right)>\frac{N}{2}\right)
$$

where $\gamma_{\mathrm{km}}$ is the probability that candidate $\mathrm{m}$ in congressional district $\mathrm{k}$ is elected, $p_{j k m}$ is the probability that candidate $\mathrm{m}$ in congressional district $\mathrm{k}$ votes for policy $\mathrm{j}$, and $p_{j k(-m)}$ is defined similarly for candidate m's opponent. There are two ways that a lobby can affect the policy outcome in this setting. First, the lobby can give campaign funds to influence the outcome of the elections, thus raising the probability that a candidate who supports the lobby's preferred position is elected. Second, the lobby can try to affect the policy stances of the candidates for office.

A rational political action committee wishing to maximize its expected profits will give campaign contributions to candidate $\mathrm{m}$ in congressional district $\mathrm{k}$ until:

$$
\frac{f E(\Pi)}{f c_{k m}}=\operatorname{Pr}^{\prime}()\left[\frac{f \gamma_{k m}}{f c_{k m}}\left(p_{j k m}-p_{j k(-m)}\right)+\gamma_{k m} \frac{f p_{j k m}}{f c_{k m}}\right]\left(\Pi_{1}-\Pi_{0}\right)+\gamma_{k m} \frac{f s_{k m}}{f c_{k m}}-1=0,
$$

where $\operatorname{Pr}^{\prime}()=\operatorname{Pr}^{\prime}\left({ }_{k=1}^{N}\left(\gamma_{k m} p_{j k m}+\left(1-\gamma_{k m}\right) p_{j k(-m)}\right)>\frac{N}{2}\right)$ is the effect of a unit increase in the total expected votes on the probability that bill $\mathrm{j}$ passes the legislature and $s_{k m}$ is the value of agenda development services provided by the candidate to the lobby. Equation (3) can be rearranged:

$$
\frac{f \gamma_{k m}}{f c_{k m}}\left(p_{j k m}-p_{j k(-m)}\right)+\gamma_{k m} \frac{f p_{j k m}}{f c_{k m}}+A \gamma_{k m} \frac{f s_{k m}}{f c_{k m}}=A
$$

where $A=\frac{1}{\operatorname{Pr}^{\prime}()\left(\Pi_{1}-\Pi_{0}\right)}$ is constant across candidates for office.

The first term in equation (4) represents the electoral motive for a political action committee to give campaign contributions. If the two candidates in a congressional district have different stances on policy $\mathrm{j}$, a lobby can affect the probability that a policy is adopted by contributing money to affect the election outcome. The effect of the lobby's campaign 
contribution on the election outcome is $\frac{f \gamma_{k m}}{f c_{k m}}$ and the effect on the expected votes in favor of policy $\mathrm{j}$ is $\frac{f \gamma_{k m}}{f c_{k m}}\left(p_{j k m}-p_{j k(-m)}\right)$. If the electoral motive is important in determining a PAC's campaign contributions, then their donations will increase if the candidate supports their position and decrease if the candidate's opponent supports their preferred policy choice.

The second term represents the policy motive for contributions. By influencing the policy positions adopted by candidates, a lobby's campaign funds can affect the expected number of votes in favor of a policy $\mathrm{j}$ in the next congress. The direct policy effect of contributions on the expected number of votes policy $\mathrm{j}$ is the probability that the candidate is elected times the effect of campaign contributions on his or her probability of voting for the policy, $\gamma_{k m} \frac{f p_{j k m}}{f c_{k m}}$. An increase in the probability that a candidate will win the election should elicit greater campaign contributions from an interest group that wants to influence the candidates' policy choice.

The last term on the LHS of equation (4) represents services that elected officials provide for lobby groups that contribute to the candidates' campaigns if they win the election. While these agenda development services are not observable, the ability of a politician to provide interest groups with valuable services is likely to rise with the legislator's position as a leader within Congress and with membership on important committees.

\section{EMPIRICAL MODEL}

This paper develops a multiple equation empirical model based on the theoretical model in the previous section to estimate the probability that a candidate wins the election, the contributions candidates receive, and the policy choices they make.

The election outcome is assumed to be a function of the personal characteristics of the two candidates and the total campaign contributions that each candidate has available to use in support of his or her campaign. Since donors give campaign funds to candidates who are more likely to win and candidates will seek more money if they are involved in a close race, the contribution variables must be treated as endogenous. The endogenous nature of contributions 
is consistent with the observed relationship between a candidate's margin of victory and campaign receipts.

Figures 1, 2, and 3 plot contributions received against the margin of victory for challengers facing other challengers, for challengers facing incumbents, and for incumbents. The pattern in all three figures is that candidates in close races receive greater contributions on average than candidates who win or lose in a landslide. For open seat elections, challengers in races in which the margin of victory is less than 20 percentage points receive $\$ 757,000$ on average in campaign contributions. Average receipts in open seat races with a margin of victory between 20 and 40 percentage are $\$ 547,000$, and average receipts in races with a greater than 40 percentage point margin of victory are $\$ 213,000$. A similar pattern emerges for incumbents, as Figure 3 shows. Those who won close races (margin<20) received $\$ 1,021,000$ on average in campaign contributions while defeated incumbents received slightly less $(\$ 812,000)$. Winners by $20-40$ percentage points amassed only $\$ 636,000$ in contributions and landslide victors garnered $\$ 503,000$ on average.

Figure 2 reveals the strong positive correlation between campaign receipts and the electoral success of challengers facing incumbents. While the average receipts by challengers facing incumbents was $\$ 253,000$, no challenger who won the election received less than $\$ 621,000$. Only three challengers who amassed $\$ 500,000$ in campaign receipts lost the election by more than 20 percentage points. This correlation can not, of course, reveal whether the contributions enable the candidates to mount a stronger challenge or whether the money flows to candidates who are expected to do well.

In order to separate out the effect of contributions on election outcomes from the effect of expected outcomes on campaign receipts, this paper estimates the following a system of equations:

$$
\begin{aligned}
& \text { votes }_{I}=F\left(a_{0}+a_{1} X+a_{2} C_{I}+a_{3} C_{C}\right)+e_{1} \\
& C_{I}=b_{0}+b_{1} Y+b_{2} C_{C}+b_{3} E\left(\text { votes }_{I}\right)+e_{2} \\
& C_{C}=d_{0}+d_{1} Z+d_{2} C_{I}+d_{3} E\left(\text { votes }_{I}\right)+e_{3}
\end{aligned}
$$

where $\mathrm{C}_{\mathrm{I}}$ and $\mathrm{C}_{\mathrm{C}}$ are the campaign contributions received by incumbents and challengers, votes $\mathrm{I}_{\mathrm{I}}$ is the percentage of the popular vote received by the incumbent, $\mathrm{E}\left(\right.$ votes $\left._{\mathrm{I}}\right)$ is the expected 
percentage of votes received by the incumbent, $\mathrm{F}$ is the cumulative standard normal distribution, and $\mathrm{X}, \mathrm{Y}$, and $\mathrm{Z}$ are vectors of exogenous explanatory variables. In the estimation, the expected outcome is equal to the predicted outcome in equation (5): E(votes $)$ $F\left(a_{0}+a_{1} X+a_{2} C_{I}+a_{3} C_{C}\right)$. The estimate of $a_{2}$ reveals the effect that campaign spending by incumbents has on the election outcome and $\mathrm{a}_{3}$ reveals the effect of spending by challengers. The model allows each candidate to respond to a strong challenge from the opponent by raising greater contributions. The coefficients $b_{2}$ and $d_{2}$ reveal the extent to which incumbents and challengers alter their fund-raising in response to the contributions raised by their opponent.

The estimates in equation (5) yield a predicted vote share for the incumbent while equations (6) and (7) determine the predicted contributions received by each candidate. In a simultaneous equation model, certain exclusion restrictions are required to identify the model. The variable excluded from the contributions equations but included in equation (5) is the margin of victory in the congressional district of the presidential candidate from the incumbent's party. This variable reflects the party strength of the incumbent representative in the district, but it should not directly affect the contributions he or she receives. The variables excluded from equation (5) are: terms in office, a dummy variable indicating if the candidate was the chair or ranking member of a committee in 1994-95, age, regional dummy variables, the incumbent's campaign receipts in the 1994 election cycle, and whether or not the candidate was involved in a primary. Each of these variables affects the candidate's ability or inclination to amass contributions without directly affecting his or her chances of success in the election. The system of equations is estimated by full-information maximum likelihood.

The second stage of the model in this paper examines the effect that campaign contributions have on the policy decisions candidates make. Candidates are assumed to make policy decisions based on personal traits, characteristics of their congressional district, and campaign contributions given by groups who support or oppose each bill. Again, the campaign contributions given by these groups are endogenous because committees will give more money to candidates who are predisposed to support the committee's preferred position. The system of equations estimated is:

$$
P_{j m}=F\left(f_{0}+f_{1} X_{d}+f_{2} X_{p m}+f_{3} I_{m}\left(C_{j m}-C_{(-j) m}\right)+f_{4}\left(1-I_{m}\right)\left(C_{j m}-C_{(-j) m}\right)\right)+e_{4}
$$




$$
C_{j m}-C_{(-j) m}=g_{0}+g_{1} Y_{p m}+g_{2} P_{j m}+g_{3} P_{j(-m)}+e_{5}
$$

where $\mathrm{P}_{\mathrm{jm}}$ is candidate $\mathrm{m}$ 's decision on policy $\mathrm{j}, \mathrm{F}$ is the cumulative standard normal distribution, $X_{d}$ is a vector of district characteristics, $X_{\mathrm{pm}}$ and $\mathrm{Y}_{\mathrm{pm}}$ are personal characteristics of candidate $m, I_{m}$ is a dummy variable indicating that candidate $m$ is an incumbent, $C_{j m}\left(C_{(-j) m}\right)$ is the contributions that candidate $\mathrm{m}$ receives from groups who support (oppose) policy $\mathrm{j}$, and $\mathrm{P}_{\mathrm{j}(-\mathrm{m})}$ is the policy decision of the opposing candidate.

Equation (8) estimates the determinants of candidates' policy choices. The statistical significance of the coefficients in the vector $f_{2}$ provide a test of whether or not personal ideology enters into candidates' decisions on policy issues. The coefficients $f_{3}$ and $f_{4}$ reveal the effects of campaign contributions on the policy stances adopted by incumbents and challengers respectively.

Equation (9) estimates the campaign contributions a candidate receives from political action committees for and against each policy stance. These contributions are determined by the personal characteristics of the candidate as well as by the policy stance adopted. The theoretical model deriving equation (4) predicts that if PACs have an electoral motive to give campaign donations, there will be a positive coefficient estimate $g_{2}$ and a negative estimate of $g_{3}$. Support for a PAC's preferred policy stance (and opposition to that stance by the candidate's electoral opponent) should lead to greater campaign contributions from the PAC. Because of difficulty attaining convergence of the parameters using full information maximum likelihood, the simultaneous equation system is estimated by general method of moments.

Five policy choices are examined in this paper. The first policy issue is support for the North American Free Trade Agreement (NAFTA) which eliminated trade barriers between the United States, Canada, and Mexico. The Heckscher-Ohlin model predicts that in the United States, which is capital-abundant relative to Mexico, capital owners will benefit from trade liberalization while the scarce factor, labor, will be hurt. Consistent with this prediction, labor groups strongly opposed NAFTA while business groups generally supported it. This paper treats contributions from business groups as being in support of NAFTA and those from labor groups as opposing NAFTA. Baldwin and Magee (1999) present evidence that campaign contributions from labor groups were associated with votes against the 1993 NAFTA bill while business group contributions were correlated with votes in favor of the bill. The Family and Medical Leave Act (FMLA), which would require businesses to provide leave for workers who 
give birth, adopt a child, or have a medical emergency, is the second policy issue examined in this paper. Political action committees representing labor groups are assumed to support this act while those representing business groups are assumed to oppose it.

A third policy issue examined in this paper is a bill proposing a ban on partial-birth abortions. Interest groups identified as pro-life are assumed to support the bill while pro-choice groups are assumed to oppose it. Candidates' positions on a proposal to cut spending for B-2 bombers are also examined. Defense Aerodynamics political action committees (identified by the Center for Responsive Politics, www.crp.org) are assumed to oppose the proposal while interest groups advocating a reduction in military spending support it. The final policy issue analyzed is the Brady bill restricting sales of handguns. Handgun control groups are assumed to support this bill while the NRA and other gun rights groups oppose it.

\section{RESULTS}

Table 1 presents the variables, the data source from which they were taken, and the means in the data set. The data are described more fully in the appendix. The average candidate was 48.5 years old, received \$520,000 in campaign contributions (about 39\% of it from PACs), made $\$ 494,000$ in campaign expenditures, and received 102,000 votes.

Table 2 presents the results of estimating equations (5) - (7). These equations are estimated using campaign contributions received by candidates rather than their expenditures. Campaign receipts and expenditures are highly correlated (correlation $=0.96$ ), however, and using expenditures rather than receipts does not change the results. Because equation (5) is nonlinear, interpreting the coefficients is difficult. Thus, the second column of numbers in Table 2 reveals the marginal effects of a unit change in the right-hand-side variables on the dependent variable, calculated from the average values of the continuous right-hand side variables and from zero for the dummy variables.

Table 2 reveals that campaign receipts by challengers in the 1996 House elections have a statistically significant negative effect on the fraction of the popular vote received by the incumbent. An increase of $\$ 100,000$ in a challenger's campaign receipts lowers the incumbent's share of the vote by 2.3 percentage points. For incumbents, however, contributions have a negligible impact on their expected vote share. An increase of $\$ 100,000$ in contributions received by the incumbent raises his or her expected fraction of the popular vote by only 0.16 
percentage points. Thus, the results in this paper support the conventional wisdom that contributions received by challengers are very important in securing victory but that receipts by incumbents do not help the reelection effort and may merely reflect a higher quality challenger. The results also support the view that restrictions on campaign spending will harm challengers more than incumbents. Based on the estimates in Table 2, the average incumbent would lose an expected 1.1 percentage points in the share of the popular vote if her contributions were reduced to zero while gaining 6.1 percentage points if the average challenger's campaign receipts were restricted to zero.

Because simultaneous equation models are very sensitive to exclusion restrictions and other assumptions of the model, this paper performs a number of robustness tests that are included in Table 2. The estimation was performed excluding outliers, defined as candidates with above $80 \%$ of the popular vote or above $\$ 3,000,000$ in campaign receipts and using an alternative estimation procedure (generalized method of moments). Coefficients whose signs reverse when outliers are excluded are marked with $\mathrm{O}$ and those that are sensitive to the estimation technique are marked E.

A final sensitivity analysis examines how robust the estimates of $a_{2}$ and $a_{3}$ (the effect of incumbent and challenger campaign receipts on election results) are to changes in the instrumental variables. The model was re-estimated excluding each variable in the contribution equations (individually) and the resulting estimates of $\mathrm{a}_{2}$ and $\mathrm{a}_{3}$ are presented in the last two columns of the second half of Table 2. The effect of challenger receipts on election outcomes $\left(a_{3}\right)$ remains large and highly significant throughout the sensitivity analysis. The impact of incumbent receipts on election outcomes does vary across the model specifications (and switches signs once), although in every case the coefficient estimate is small.

The other coefficients in the election outcome equation have the expected signs. Incumbents facing challengers who have held previous office or who were the previous party nominee for the House of Representatives have 1.5 and 2.8 percentage point lower vote shares on average. A rise of 1 percentage point in the margin of victory by presidential candidate in 1996 in the incumbent's party means a 0.2 percentage point increase in the incumbent's 
expected vote share. Each term in office is also associated with a 0.2 percentage point increase in the incumbent's fraction of the popular vote.

Table 3 presents the results of estimating the NAFTA and Family and Medical Leave Act policy decisions and the contributions received from labor and business groups. The two issues are estimated simultaneously since labor and business groups may have both policy issues in mind when they make campaign contributions. The table presents the coefficient estimate as well as the marginal effect of a unit change in the right-hand side variable on the dependent variable. The contribution variable in this table is the difference between business (proNAFTA, anti-FMLA) contributions and labor (anti-NAFTA, pro-FMLA) contributions. The baseline probability reveals the model's predicted probability of support for the bill from an otherwise average candidate with even contributions from business and labor groups and with dummy variables set to zero.

Campaign contributions from business groups and labor groups have no statistically significant effect on either challenger or incumbent positions on NAFTA. For challengers, the insignificance of the coefficient reflects a large standard error rather than a small coefficient. A $\$ 1000$ increase in business contributions raises a challenger's likelihood of voting for NAFTA by 0.76 percentage points but lowers the probability an incumbent will vote for NAFTA by 0.04 percentage points. The other right-hand side variables affect representatives' policy choices in an expected manner. Congressmen from districts with export-oriented employment, that were largely Hispanic, and where the union presence was weak were more likely to support NAFTA. Consistent with the view that NAFTA would harm low-skill workers, representatives from districts with a high proportion of residents without a high school degree tended to oppose NAFTA.

Contributions do have a statistically significant effect on incumbents' policy stances on the Family and Medical Leave Act, but the sign of the coefficient is contrary to expectations and the estimated impact on support for the act is small. The greater the campaign contributions an incumbent receives from labor groups relative to business groups, the more likely it is he or she will oppose the FMLA. Contributions do not significantly affect the policy stances adopted by challengers, although the point estimates of the coefficients are very similar. A $\$ 1000$ increase in labor contributions lowers the probability of supporting the FMLA by 0.08 and 0.1 percentage points for challengers and incumbents respectively. Democrats from strongly 
unionized districts, particularly those districts that voted Democratic in the 1996 presidential election, were more likely to support the FMLA.

The last part of Table 3 shows the factors affecting how much financial support a candidate receives from business groups relative to labor groups. An electoral motive for campaign contributions suggests that PACs will give more money to candidates who adopt their favored position and less money to a candidate whose opponent also adopts the interest group's favored policy stance. The coefficients on the NAFTA and the FMLA policy choice variables show that business PACs gave more and labor PACs gave less money to candidates who supported NAFTA and to those who opposed the FMLA. A NAFTA supporter received about $\$ 73,000$ more from business groups (net of labor contributions) than a NAFTA opponent. An FMLA opponent received about $\$ 122,000$ more from business groups (net of labor contributions) than an FMLA supporter. On both bills, the policy stance adopted by the opponent of a candidate had only a small and statistically insignificant effect on his or her receipts from business and labor groups.

The results in Table 3 also suggest that PACs gave campaign donations with an eye toward the agenda development services that incumbent legislators could provide. Incumbents who were members of the House Ways and Means Committee received about \$98,000 more from business groups while membership on the Commerce Committee raised contributions from business groups by $\$ 99,000$ relative to the donations of labor groups. Members of the Education and Labor committee and members of the labor subcommittee of Appropriations, on the other hand, received $\$ 55,000$ and $\$ 48,000$ more from labor groups, respectively. Incumbents who were the chair or ranking member of committees or who had a leadership position in Congress received $\$ 38,000$ more contributions from business groups (relative to their labor receipts) than did otherwise identical incumbents without a leadership position.

Table 4 presents the results of estimating the abortion policy decisions and the contributions from groups interested in this issue. As with NAFTA and FMLA, campaign contributions do not significantly affect the policy stance adopted by candidates, but campaign donations do flow to candidates who support the interest groups' preferred position. Candidates who supported the ban on partial-birth abortions received over $\$ 4000$ more from pro-life groups net of pro-choice contributions. This difference in donations represents an enormous increase, considering that the average candidate received only $\$ 1,260$ from pro-life groups and $\$ 710$ from pro-choice groups. Also consistent with an electoral motive for PAC giving is the estimate 
showing that pro-life groups reduced their donations by over $\$ 800$ if the candidate's opponent was also in favor of the ban on partial-birth abortions. The abortion policy stance was split largely along party lines, as evidenced by the very large coefficient estimate on the Democrat variable.

The determinants of national defense policy positions and the contributions from interested PACs are presented in Table 5. Defense spending is the only policy choice in which campaign contributions significantly sway incumbents to vote in the interest group's preferred manner. A reduction in contributions received by the defense lobby of $\$ 1000$ raises the incumbent's probability of voting for the reduction in defense spending by about 2.5 percentage points. Challengers' policy positions on this issue were not statistically significantly affected by campaign contributions, although the estimated coefficient is quite large. Some evidence that "hawk" PACs have an influence motive is given by the estimate that members of the national security committee receive $\$ 11,558$ more in campaign contributions from defense PACs relative to "dove" groups. These targeted donations represent an increase of over four times the average defense lobby contributions to candidates $(\$ 2650)$.

Unlike the other policy issues examined, contributions from the defense lobby and from "dove" groups do not significantly respond to the defense spending policy choice adopted by the candidates. The coefficient estimate on the B-2 bomber bill variable in the contribution equation, while not statistically significant, is positive and economically nontrivial. A candidate who supports a reduction in defense spending received, on average, about $\$ 1641$ less from defense groups than an otherwise identical "defense hawk." The positive coefficient on the opponent's policy stance, however, is inconsistent with an electoral motive for contributing.

Both district and personal characteristics affected a candidate's stance on reducing military spending. Candidates were less likely to vote for reductions in spending if there was considerable military employment in the congressional district. Every 1,000 workers employed by the military in the district reduced by 1.8 percentage points the likelihood that a candidate would support reductions in defense spending. Candidates who had served in the military themselves were also 16.5 percentage points less likely to vote for cutting defense spending.

The factors affecting candidates' decisions about gun control and the contributions from interested political action committees are presented in Table 6. The coefficients on contributions received by challengers and incumbents from gun control groups are both positive (and the challenger point estimate is quite large), but neither is statistically significant. Both 
district and personal characteristics of candidates affect their gun control policy decision. Candidates are more likely to support gun control if they represent wealthy districts in states with a large police force relative to the population. Women and democrats are also more likely to support gun control.

The coefficient estimates in the second half of Table 6 provide strong evidence that political action committees interested in gun control issues are giving money primarily from an electoral motive. Contributions from gun control groups (net of contributions from gun right groups) rise by about $\$ 6600$ when a candidate supports the Brady bill. Furthermore, these contributions fall by about $\$ 1300$ when a candidate's opponent also supports the Brady bill. Both coefficients are statistically significant at the $1 \%$ level.

The results in Tables $3-7$ suggest that campaign contributions respond to candidates' policy stances rather than influencing them. In only one case out of five examined did the contributions significantly affect the policy position adopted by incumbents in the expected manner, and contributions never significantly influenced challengers' policy stances. For four of the five issues examined, however, the candidates' policy positions significantly affected the pattern of campaign contributions that they received (at the $1 \%$ level). Further evidence in favor of the electoral motive is shown by the statistically significant negative coefficients on the opponent's policy decision in two of the five policy stances examined. In these cases, interest groups supporting a particular act gave less money to a candidate if his or her opponent supported the act.

The one policy decision that breaks the pattern described above is national defense spending. For that issue, campaign contributions did not significantly respond to candidates' policy stances (and the coefficient on the opponent's policy stance variable was positive). Campaign contributions did significantly affect the national defense policy positions adopted by incumbents.

\section{CONCLUSION}

The results in this paper suggest that political action committees give money to challengers primarily to affect the probability that the candidate is elected. Campaign contributions received by challengers have a large effect on the outcome of the election, but in none of the five policy issues examined in this paper do they affect the candidate's policy stance. 
Consistent with an electoral motive for donations, however, the pattern of campaign contributions received by candidates was significantly affected by their policy stances on four of the five issues. In two of the five policy choices, the opponent's policy decision also significantly affected the contributions a candidate received.

Some evidence is presented here that political action committee donations to incumbent campaigns are given for an influence motive. Consistent with the conventional wisdom, contributions received by incumbents did not raise their likelihood of winning the election. Most campaign contributions to incumbents appear to be given to gain services that elected officials can provide influencing the legislative agenda rather than to affect the candidate's policy stance. In only one of the five issues examined, national defense spending, did campaign contributions raise the probability that incumbents running for re-election would support the interest groups' preferred policy positions. Contributions flowed more readily, however, to members of committees with control over legislation important to the interest groups. 


\section{APPENDIX}

The policy positions taken by candidates for the House of Representatives come from a survey by Congressional Quarterly. Each candidate was asked his or her policy stances on a number of issues, including defense spending, abortion, medical leave from work, gun control, and international trade. The questions asked of each candidate are listed below.

This paper examines only elections in which there was both a democrat and republican vying for the general election. Of the 435 congressional districts, eighteen were uncontested races while two elections were won by independent candidates. The data set in this paper includes the 830 candidates in the other 415 elections. Of these, 667 responded to the Congressional Quarterly survey and gave their policy positions. The data were supplemented with responses to Project Vote Smart's National Political Awareness Test (NPAT), which also surveyed candidates on their policy positions. The NPAT identified an additional 52 candidates' positions on NAFTA, 24 positions on the Brady bill, and 28 candidates' positions on partial-birth abortion.

The proportion of private sector workers in each congressional district who were members of unions in 1991-92 is from Box-Steffenmeier, Arnold, and Zorn (1997). Presidential voting by district is available in the Almanac of American Politics. Other information such as military employment and per-capita income is from county level data at the Bureau of Economic Analysis' Regional Economic Information System at http://fisher.lib.virginia.edu/reis/county.html. These county level data were mapped into congressional districts using data on the fraction of each county's population that lived in a particular congressional district in 1990 (available in Congressional Districts in the 1990's). Congressional districts' ratios of export employment to import employment were obtained similarly using county level employment data from County Business Patterns.

\section{Congressional Quarterly's survey questions}

1. Would you have voted for legislation to implement the "NAFTA" trade agreement, which linked the United States, Canada, and Mexico in a free-trade zone and required each country to eliminate numerous tariffs and trade barriers? 
2. Would you have voted for the Family and Medical Leave Act which requires many businesses to provide workers with up to 12 weeks of unpaid leave for the birth or adoption of a child or a medical emergency?

3. Would you have voted for the bill to ban so-called "partial-birth" abortions, in which the doctor removes the fetus' brain tissue after bringing the fetus into the birth canal? Under the bill, doctors who perform the procedure could be subject to criminal and civil penalties.

4. Would you have voted for the amendment to cut $\$ 493$ million provided for continued production of B-2 stealth bombers?

5. Would you have voted for the "Brady bill" which requires each would-be purchaser of a handgun to wait five days, during which local law enforcement officials conduct a personal background check on the purchaser? 


\section{Figure 1}

\section{Challengers Facing Challengers}

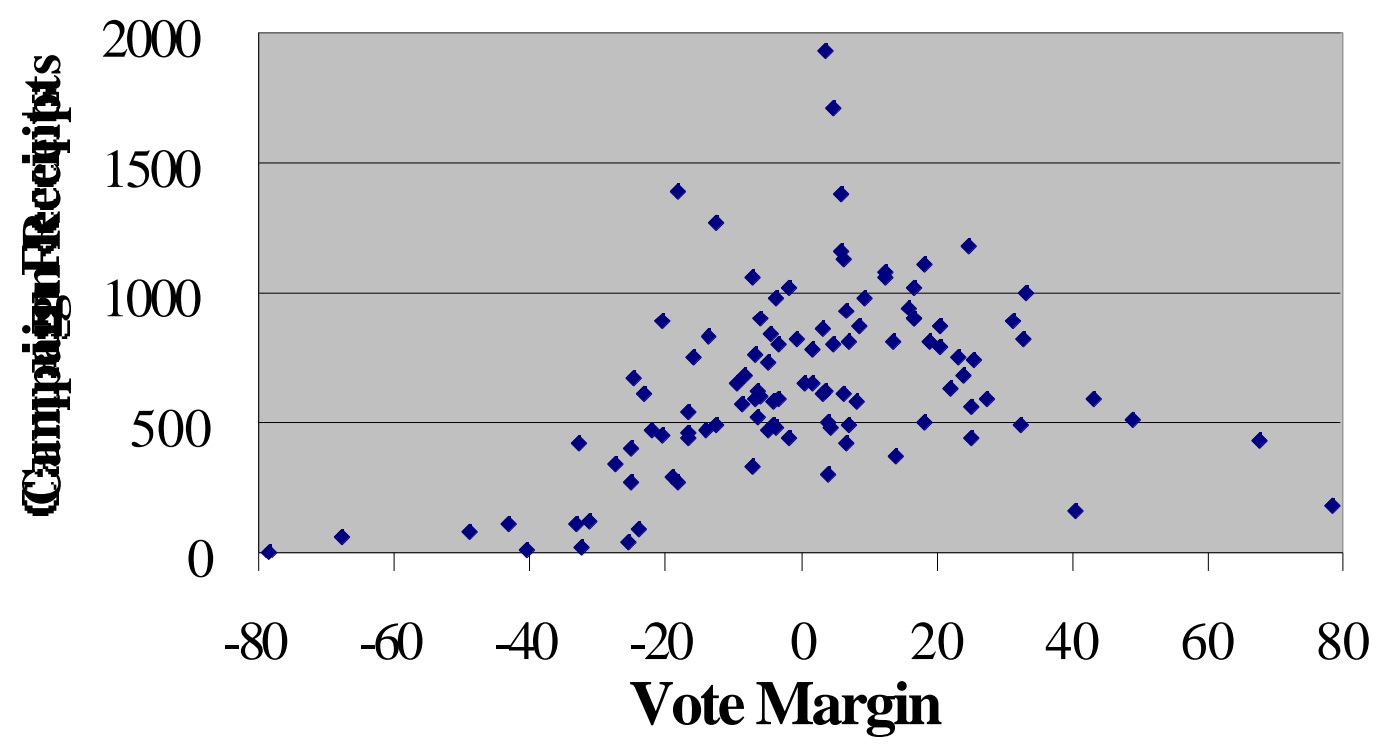

Figure 2

Challengers Facing Incumbents






\section{Figure 3}

\section{Incumbents}

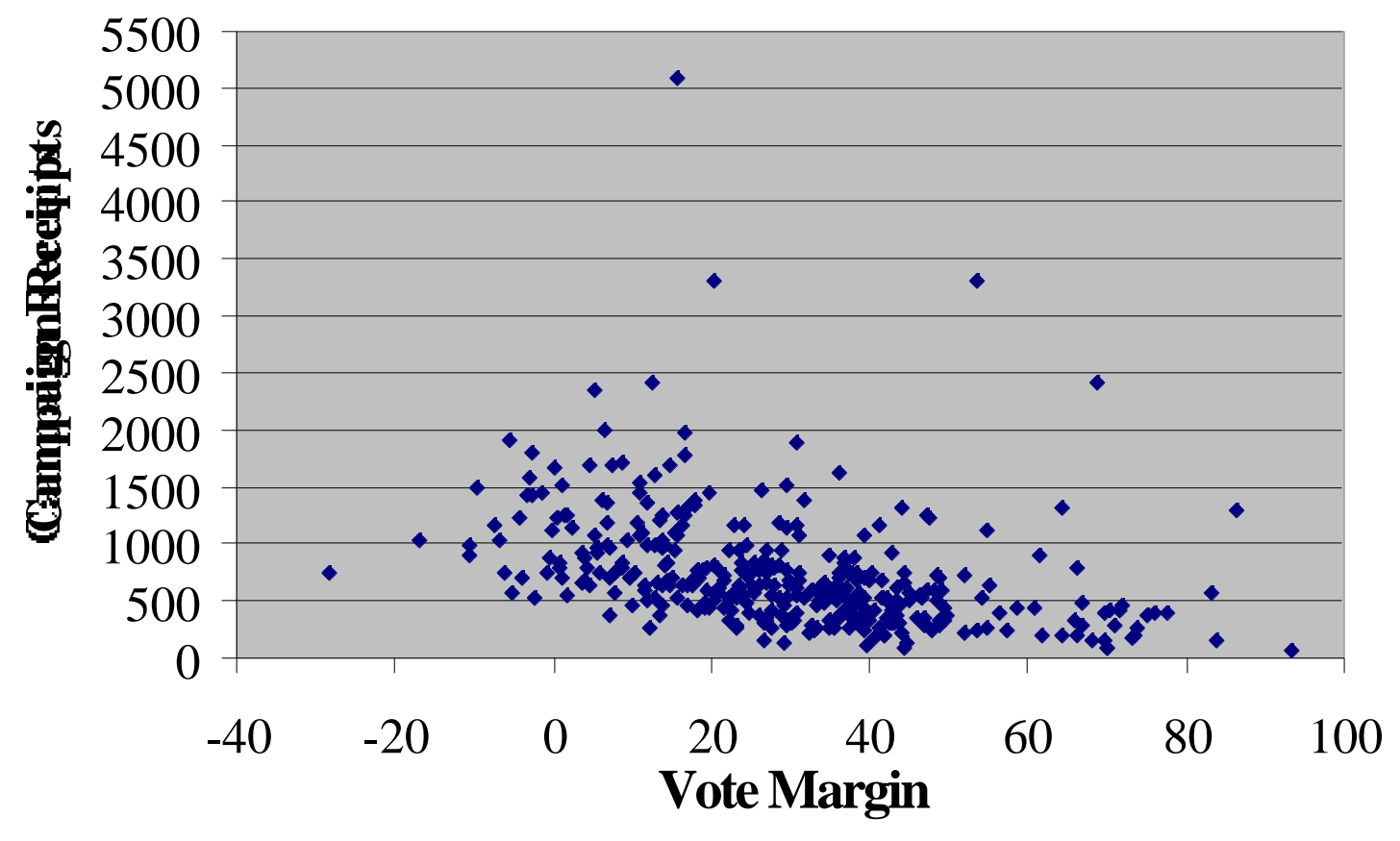


Table 1 (Means)

Description

Source

Mean

\section{Policy Positions}

$\begin{array}{llll}\text { NAFTA } & \text { 1=vote for NAFTA } & \text { CQ survey } & 0.51 \\ \text { Family Leave Act } & 1=\text { vote for Family and Medical Leave Act } & \text { CQ survey } & 0.66 \\ \text { Abortion Bill } & 1=\text { vote to ban partial-birth abortions } & \text { CQ survey } & 0.61 \\ \text { Defense Spending } & \text { 1=vote to cut B2 bomber spending } & \text { CQ survey } & 0.54 \\ \text { Gun Control } & \text { 1=vote for Brady Bill } & \text { CQ survey } & 0.54\end{array}$

\section{Personal Candidate Characteristics}

$\begin{array}{lllr}\text { Votes } & \text { Votes for candidate } & \text { www.fec.gov } & 102391.4 \\ \text { Married } & \text { 1= candidate is married } & \text { CQ survey } & 0.80 \\ \text { Children } & \text { 1=candidate has children } & \text { CQ survey } & 0.81 \\ \text { Male } & \text { 1=candidate is male } & \text { CQ survey } & 0.86 \\ \text { Military Service } & 1=\text { candidate did military service } & \text { CQ survey } & 0.31 \\ \text { Incumbent } & 1=\text { incumbent } & \text { Politics in America } & 0.44 \\ \text { Age } & \text { Age of candidate } & \text { CQ survey } & 48.50 \\ \text { Catholic } & 1=\text { candidate is catholic } & \text { CQ survey } & 0.29 \\ \text { Terms } & \text { Terms in office } & \text { Politics in America } & 1.89 \\ \text { Nominee } & 1=\text { previous nominee for House } & \text { CQ survey } & 0.58 \\ \text { Office } & 1=\text { held elected office } & \text { CQ survey } & 0.69\end{array}$

\section{Campaign Contribution Data}

$\begin{array}{lllr}\text { Contributions } & \text { Total campaign contributions }(\$ 000) & \text { FEC data } & 520.31 \\ \text { Disbursements } & \text { Total campaign expenditures }(\$ 000) & \text { FEC data } & 493.70 \\ \text { Contributions (Incum) } & \text { Incumbent campaign contributions }(\$ 000) & \text { FEC data } & 725.53 \\ \text { Contributions (Chall.) } & \text { Challenger campaign contributions }(\$ 000) & \text { FEC data } & 339.57 \\ \text { Disbursements (Incum) } & \text { Incumbent campaign expenditures }(\$ 000) & \text { FEC data } & 667.84 \\ \text { Disbursements (Chall) } & \text { Challenger campaign expenditures }(\$ 000) & \text { FEC data } & 333.62 \\ \text { Prochoice } & \text { Pro-Choice Contributions }(\$ 000) & \text { FEC data } & 0.71 \\ \text { Prolife } & \text { Pro-Life Contributions }(\$ 000) & \text { FEC data } & 1.26 \\ \text { Pronafta } & \text { Pro-NAFTA, anti-Fam Lv Cont. }(\$ 000) & \text { FEC data } & 57.88 \\ \text { Anti-NAFTA } & \text { Anti-NAFTA, pro-Fam Lv Cont. }(\$ 000) & \text { FEC data } & 45.96 \\ \text { Probrady } & \text { Contributions supporting Brady Bill }(\$ 000) & \text { FEC data } & 0.06 \\ \text { Anti-Brady } & \text { Contributions opposing Brady Bill }(\$ 000) & \text { FEC data } & 3.04 \\ \text { Pro-B2 Bomber } & \text { Pro-B2 Bomber cut contributions }(\$ 000) & \text { FEC data } & 0.07 \\ \text { Anti-B2 Bomber } & \text { Anti-B2 Bomber cut contributions }(\$ 000) & \text { FEC data } & 2.65\end{array}$


Table 1 (Cont.)

Description

Committee Membership

Committee Chair
Education and Labor
Ways and Means
Trade
Commerce
Small Business
Budget
Military Construction
National Security
Veterans Committee
Judiciary
Labor (Sub)

1=Chair/Ranking Committee Member

$1=$ Education and Labor Committee

$1=$ on Ways \& Means Committee

$1=$ on Trade Subcommittee

$1=$ on Commerce Committee

$1=$ on Small Business Committee

$1=$ on Budget Committee

$1=$ on Military Construction Subcommittee

$1=$ on National Security Committee

$1=$ on Veterans Committee

$1=$ on Judiciary Committee

1=Labor Subcommittee of Appropriations
Politics in America

0.07

Source

Mean

Politics in America

0.04

Politics in America

0.04

0.01

0.05

0.04

0.04

0.01

0.05

0.03

0.04

0.02

\section{District Characteristics}

No High School Degree \% in district without a high school degree

Percentage Hispanic

Export Ratio

Over 65

Military

Per-Capita Income

Clinton

Dole

Union

\section{State Characteristics}

$\begin{array}{ll}\text { Veterans } & \text { State \% veterans } \\ \text { Airforce } & \text { AF personnel per 1,000 } \\ \text { Police } & \text { Police per 10,000 pop. } \\ \text { Violent crime } & \text { Violent crimes per 100,000 } \\ \text { Metropolitan } & \text { \% of state in MSA } \\ \text { Abortions } & \text { Abortions per 1000 women (15-44) } \\ \text { Teen Births } & \text { Births to teens, \% of total }\end{array}$

US Census $\quad 0.25$

US Census $\quad 8.66$

County Business Patterns $\quad 1.39$

US Census $\quad 0.12$

Regional Economic $\quad 5.03$

Information System (BEA)

Regional Economic

Information System (BEA)

Almanac of American $\quad 50.13$

Politics

Almanac of American $\quad 40.03$

Politics

Box-Steffensmeier, Arnold, and Zorn (1997)
Statistical Abstract of US $\quad 0.10$

Statistical Abstract of US $\quad 1.22$

Statistical Abstract of US $\quad 24.89$

Statistical Abstract of US $\quad 625.00$

Statistical Abstract of US $\quad 80.10$

Statistical Abstract of US $\quad 22.77$

Statistical Abstract of US $\quad 12.70$ 


\section{ELECTION OUTCOME EQUATION}

\section{Table 2}

\section{Variables}

Contributions

Incumbent Contributions

Challenger Contributions

Instrumental Variables

Presidential Vote

Other Variables

Office

Nominee

Democrat

Terms

Constant

R-squared
Incumbent Vote Fraction Coefficients

Marginal Effects

$\begin{array}{cr}0.00004 & 0.0016 \\ -0.00061 * * * & -0.0233 \\ & \\ 0.00458 * * * & 0.1766\end{array}$

0.03968

$0.07173 *$

$-0.00193$

$0.00497 * * *$

$0.31603 * * *$

0.5643
Sensitivity Analysis

O E

\section{Campaign Contribution Equations}

\section{Variables}

Incumbent Fraction of Vote

Opponent Contributions

Instrumental Variables

Northeast

South

West

Age

Primary

Committee Chair

1994 Receipts

Ways and Means Committee

\section{Other Variables}

Office

Nominee

Democrat

Terms in Office

Constant

R-squared

Observations

Log Likelihood

\section{Challenger Receipts Coefficients}

$$
\begin{array}{r}
-2059.9800 * * * \\
0.1474 * * *
\end{array}
$$

$$
-8.4499
$$$$
8.6176
$$

$57.5124 * * *$

$-0.1632$

$48.5719 * *$

\section{Incumbent Receipts \\ Coefficients}

$-997.3556$

$-0.0975$

E O

0.7636

35.9325

$-9.5290$

$-11.7625 * * *$

40.8117

113.0473

$0.9164 * * *$

55.3380

-2.0325
-74.0952
-46.9722

$1482.8800 * * *$
0.5143
350
-4479

\section{Sensitivity Analysis}

$\mathbf{a}_{2}$

$\mathbf{a}_{3}$

$0.00014 * * \quad-0.0010 * * *$

$-0.00005 * \quad-0.0005 * * *$

$\mathrm{O}, \mathrm{E}$ indicate that the coefficient sign is sensitive to outliers or to the estimation procedure (GMM/FIML) $*, * *, * * *$ Indicate that the coefficient is statistically significant at the $10 \%, 5 \%$, and $1 \%$ levels 
NAFTA Policy Decision

Table 3

Dependent Variable: 1 = Candidate Supports the North American Free Trade Agreement

Variables

Contributions (Challenger)

Contributions (Incumbent)

District Characteristics

Export Ratio

Percentage Hispanic

Union

Per-capita Income

No High School Degree

Votes for Clinton

Personal Characteristics

Democrat

Constant

Baseline Probability

$\mathrm{R}^{2}$

\section{Coefficients}

0.0197

$-0.0009$

$0.3520 * *$

$0.0211 * * *$

$-0.0241 *$

0.0218

$-2.9251 * *$

$-0.0246 * *$

$-0.4366$

$1.3761 * *$

0.6003

0.0878
Marginal Effect

0.7600

$-0.0350$

12.7491

0.8137

$-0.9325$

0.8404

$-59.6507$

$-0.9538$

$-17.2676$

Family and Medical Leave Act Policy Decision

Dependent Variable: 1 = Candidate Supports the Family and Medical Leave Act

Variables

Contributions (Challenger)

Contributions (Incumbent)

District Characteristics

Union

Votes for Clinton

\section{Personal Characteristics}

Children

Married

Male

Democrat

Constant

Baseline Probability

$\mathrm{R}^{2}$

\section{Coefficients}

$-0.0025$

$-0.0032 * *$

$0.0631 * * *$

$0.0742 * * *$

0.1898

$-0.2322$

$-0.2335$

$4.1985 * * *$

$-5.3747 * * *$

0.2348

0.5679
Marginal Effect

$-0.0753$

$-0.0996$

1.9824

2.3379

6.2110

$-6.5092$

$-6.5434$

76.4917 


\section{Table 3 (Cont.)}

\section{Contribution Equation}

\section{Dependent Variable $=$ Business Contributions - Labor Contributions}

Variables

\section{Policy Choices}

NAFTA

NAFTA (opp)

Family Lv Act

Family Lv Act (opp)

Personal Characteristics

Committee Chair

Ways and Means

Commerce

Small Business

Education and Labor

Labor (Subcommittee)

Terms

Incumbent

Office

Nomination

Democrat

Receipts

Constant

$\mathrm{R}^{2}$

Observations

\section{Coefficients}

$$
\begin{gathered}
72.9601 \text { *** } \\
-0.6320 \\
122.0212 \text { *** } \\
13.6068
\end{gathered}
$$

$$
\begin{gathered}
38.2940 * * \\
98.2029 * * * \\
98.7934 * * * \\
38.9971 \\
-54.7758 * * * \\
-48.4697 * \\
0.5698 \\
35.0100 * * * \\
-36.2078 * * * \\
-8.5699 \\
-2.2972 \\
0.0455 * * * \\
\\
46.4801 * \\
\\
0.3897 \\
382
\end{gathered}
$$

$*, * *, * * *$ Indicate that the coefficient is statistically significant at the $10 \%, 5 \%$, and $1 \%$ levels 


\section{Table 4}

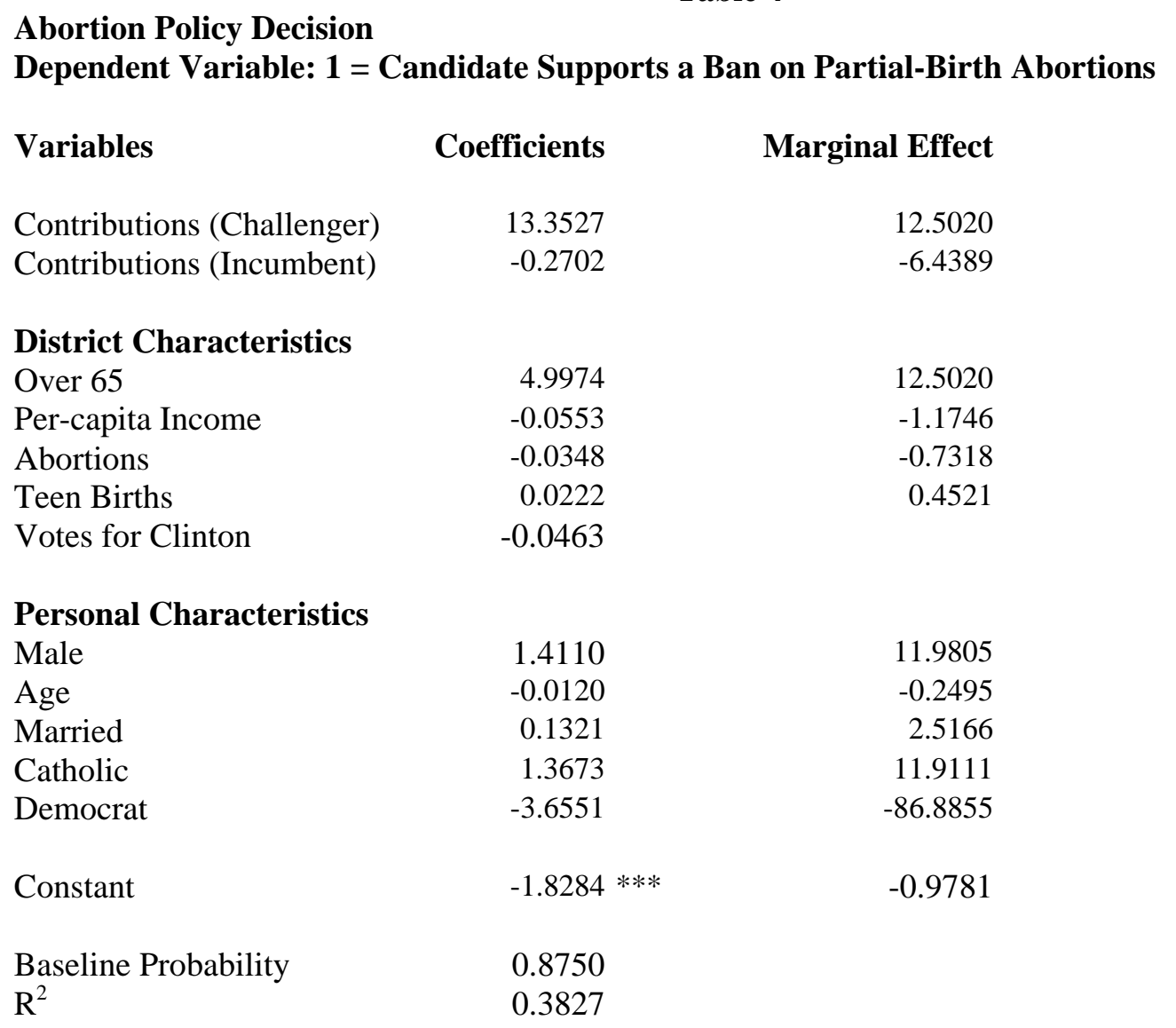

\section{Contribution Equation}

Dependent Variable $=$ Pro-life Contributions - Pro-choice Contributions

\section{Variables}

\section{Policy Decisions}

Abortion Bill

Abortion Bill (opp)

\section{Personal Characteristics}

Committee Chair

Judiciary

Terms

Incumbent

Office

Nomination

Democrat

Receipts

Constant

$\mathrm{R}^{2}$

Observations

\section{Coefficients}

$$
\begin{array}{r}
4.0084 * * * \\
-0.8127 * *
\end{array}
$$

$$
\begin{gathered}
0.9488 \\
0.5506 \\
-0.0927 \\
-1.5347 \\
0.3115 \\
1.5018 * \\
0.3114 \\
-0.0007 * \\
-1.8284 * * * \\
0.1518 \\
521
\end{gathered}
$$

$*, * *, * * *$ Indicate that the coefficient is statistically significant at the $10 \%, 5 \%$, and $1 \%$ levels 


\section{Table 5}

National Defense Policy Decision

Dependent Variable: 1 = Candidate Supports a Reduction in Spending for B-2 Bombers

$\begin{array}{lcr}\text { Variables } & \text { Coefficients } & \text { Marginal Effect } \\ \text { Contributions (Challenger) } & 3.6219 & 51.0041 \\ \text { Contributions (Incumbent) } & 0.0632 * * * & 2.5222 \\ & & \\ \text { District Characteristics } & & 51.0202 \\ \text { Veterans } & 13.9059 * * & -1.9454 \\ \text { Air Force } & -0.0488 & -1.7590 \\ \text { Military Employment } & -0.0442 * * * & -0.0456 \\ \text { Votes for Clinton } & -0.0011 & \\ \text { Personal Characteristics } & & -16.4816 \\ \text { Military Service } & -0.4282 * * * & -3.5967 \\ \text { Male } & -0.0904 & 32.7484 \\ \text { Democrat } & 0.9306 * * * & \\ \text { Constant } & -1.0175 & \\ \text { Baseline Probability } & 0.4898 & \\ \mathrm{R}^{2} & 0.2088 & \end{array}$

\section{Contribution Equation}

Dependent Variable $=$ Defense Industry Contributions - "Dove" Group Contributions

Variables

Policy Decisions

B-2 Bomber Bill

B-2 Bomber (opp)

Personal Characteristics

Committee Chair

Military Construction

National Security

Budget

Veterans Committee

Terms

Incumbent

Office

Nomination

Democrat

Receipts

Constant

$\mathrm{R}^{2}$

Observations

\section{Coefficients}

1.6414

$1.2291 *$

$$
\begin{gathered}
-1.5368 \\
1.1717 \\
-11.5581 * * * \\
1.0365 \\
1.2285 \\
-0.3266 * * \\
-1.0436 \\
0.5573 \\
-0.2401 \\
0.4980 \\
-0.0035 * * * \\
\\
-1.0720 \\
\\
0.4520 \\
467
\end{gathered}
$$

$*, * *, * * *$ Indicate that the coefficient is statistically significant at the $10 \%, 5 \%$, and $1 \%$ levels 
Gun Control Policy Decision

Table 6

Dependent Variable: 1 = Candidate Supports the Brady Bill Restricting Handgun Sales

Variables

Contributions (Challenger)

Contributions (Incumbent)

District Characteristics

Per-capita Income

Police

Violent Crimes

Metropolitan

Votes for Clinton

Personal Characteristics

Male

Military Service

Democrat

Constant

Baseline Probability

$\mathrm{R}^{2}$

Contribution Equation

Dependent Variable = Gun Control Group Contributions - Gun Rights Group Contributions

Variables

\section{Coefficients}

Policy Decisions

Brady Bill

Brady Bill (opp)

Personal Characteristics

Committee Chair

Terms

Incumbent

Office

Nomination

Democrat

Receipts

Constant

$\mathrm{R}^{2}$

Observations
146.2041

0.0843

$0.0837 * * *$

$0.0414 *$

$-0.0003$

0.0093

0.0089

$-0.4711 * *$

0.0726

$1.5355 * * *$

$-4.1755$

0.4606

0.4831

\section{Coefficients}

Marginal Effect

53.9353

3.3559

3.3314

1.6460

$-0.0108$

0.3556

$-17.6261$

2.8893

46.3958
0.3700

$*, * *, * * *$ Indicate that the coefficient is statistically significant at the $10 \%, 5 \%$, and $1 \%$ levels 


\section{REFERENCES}

Abramowitz, A., 1988, "Explaining Senate Election Outcomes," American Political Science Review 82, 385 - 403.

Baldwin, R. and C. Magee, 1999, "Explaining Congressional Voting on Trade Bills in the 1990's: From NAFTA approval to Fast-Track Defeat," forthcoming Institute for International Economics book.

Bender, B. and J. Lott, 1996, "Legislator Voting and Shirking: A Critical Review of the Literature," Public Choice 87, 67 - 100.

Box-Steffenmeier, J., L. Arnold, and C. Zorn, 1997, “The Strategic Timing of Position Taking in Congress: A Study of the North American Free Trade Agreement," American Political Science Review 91, 324 - 338.

Bronars, S. and J. Lott, 1997, “Do Campaign Donations Alter How a Politician Votes? Or, Do Donors Support Candidates Who Value The Same Things That They Do?” Journal of Law and Economics 40, 317 - 350.

Chappell, H., 1982, “Campaign Contributions and Congressional Voting: A Simultaneous Probit-Tobit Model," Review of Economics and Statistics, 77-83.

Congressional Districts in the 1990's: A Portrait of America, 1993, Washington, D.C.: Congressional Quarterly Inc.

Green, D. and J. Krasno, 1988, "Salvation for the Spendthrift Incumbent: Reestimating the Effects of Campaign Spending in House Elections," American Journal of Political Science 32, 884 - 907.

Grossman, G. and E. Helpman, 1996, "Electoral Competition and Special Interest Politics," Review of Economic Studies 63, 265 - 286.

Jacobson, G., 1978, “The Effects of Campaign Spending in Congressional Elections,” American Political Science Review 72, 469 - 491.

Jacobson, G., 1985, "Money and Votes Reconsidered: Congressional Elections, 1972 - 1982," Public Choice 47, 7 - 62.

Levitt, S., 1994, "Using Repeat Challengers to Estimate the Effects of Campaign Spending on Election Outcomes in the U.S. House," Journal of Political Economy 102, 777 - 798.

Levitt, S., 1995, “Policy Watch: Congressional Campaign Finance Reform,” Journal of Economic Perspectives 9, 183 - 193. 
Morton, R. and C. Cameron, 1992, "Elections and the Theory of Campaign Contributions: A Survey and Critical Analysis," Economics and Politics 4, 79 - 108.

Poole, K. and T. Romer, 1985, "Patterns of Political Action Committee Contributions to the 1980 Campaigns for the U.S. House of Representatives," Public Choice 47, 63 - 111.

Stratmann, T., 1991, "What Do Campaign Contributions Buy? Deciphering Causal Effects of Money and Votes," Southern Economic Journal 57, 606 - 620.

Stratmann, T., 1992, “Are Contributors Rational? Untangling Strategies of Political Action Committees," Journal of Political Economy 100, 647 - 664.

Stratmann, T., 1998, “The Market for Congressional Votes: Is Timing of Contributions Everything?" Journal of Law and Economics 41, 85 - 113. 